\title{
FAKTOR-FAKTOR PENYEBAB PEDAGANG BERTAHAN DI PASAR LAMA KECAMATAN LUBUK ALUNG KABUPATEN PADANG PARIAMAN
}

\author{
Widya Rahmawati ${ }^{1}$, Surtani ${ }^{2}$, Fitriana Syahar ${ }^{2}$ \\ Program Studi Pendidikan Geografi, \\ Fakultas Ilmu Sosial, \\ Universitas Negeri Padang \\ Email: widyarahmawati2001@gmail.com
}

\begin{abstract}
Abstrak
Penelitian ini bertujuan untuk mengetahui dan menganalisis faktor-faktor penyebab pedagang bertahan di pasar lama Kecamatan Lubuk Alung serta sikap pedagang dan pembeli terhadap pasar baru yang telah dibangun. Jenis penelitian adalah penelitian kualitatif. Teknik dalam menentukan informan yaitu Purposive Sampling sebanyak 20 informan. Hasil penelitian menemukan 1) Faktor langsung yang mepengaruhi adalah (a) Lokasi pasar dekat dengan rumah pedagang dan pembeli jarak tempuh rata-rata kurang dari $3 \mathrm{Km}$. (b) Transportasi yang digunakan ke pasar lama yaitu kendaraan umum dan pribadi. (c) Harga sewa kios yang terjangkau Rp 500.000 - Rp 1.500 .000 pertahun. (d) Rata-rata pendapatan pedagang berkisar Rp 500.000 - Rp 1.000 .000 perhari. Faktor tidak langsung yang mempengaruhi yaitu (a) Tidak ada ketegasan pengelola pasar secara resmi untuk memindahkan pedagang dari pasar lama kepasar baru. (b) Hubungan sosial kemasyarakatan pedagang dengan lingkungan sekitar terjalin dengan baik, 2) Sikap pedagang dan pembeli terhadap pasar baru umumnya tidak setuju, karena status penempatan pedagang di pasar baru belum jelas, pedagang sudah merasa nyaman di pasar lama, biaya sewa yang mahal.
\end{abstract}

Kata Kunci : Faktor penyebab pedagang bertahan, sikap pedangang dan pasar lama.

\section{Abstarct}

This purpose of reaserch is to find out and analyze the factors that cause traders to survive in the old market Lubuk Alung District and the attitude of traders and buyers to new markets that have been built. This type of research is qualitative research. The technique in determining informants is Purposive Sampling as many as 20 informants. The results of the study found that 1) the direct influencing factors were (a) the market location close to the homes of traders and buyers, the average distance was less than $3 \mathrm{Km}$. (b) Transportation used to old markets, namely public and private vehicles. (c) Affordable kiosk rental prices of IDR 500,000 - IDR 1,500,000 per year. (d) The average income of traders ranges from Rp. 500,000 - Rp. 1,000,000 per day. Indirect factors that influence are (a) There is no official firmness of the market manager to move traders from the old market to new markets. (b) Community social relations with traders and the surrounding environment are well-established, 2) The attitude of traders and buyers to new markets generally does not agree, because the status of placement of traders in new markets is unclear, traders already feel comfortable in the old market, expensive rental costs.

Keywords: Factors that cause traders to survive, attitude of traders and old markets.

\footnotetext{
1 Mahasiswa Program Studi Pendidikan Geografi

${ }^{2}$ Dosen Jurusan Geografi Fakultas Ilmu Sosial Universitas Negeri Padang
} 


\section{PENDAHULUAN}

Sumatera Barat merupakan dareah beriklim tropis yang kaya akan sumberdaya alam karena mendapatkan sinar matahari dan curah hujan yang cukup. Mayoritas masyarakatnya bermata pencaharian sebagai petani, nelayan dan pedagang. Hasil mata pencaharian masyarakat akan dijual di pasar, baik pasar modern maupun pasar tradisional. Dalam Peraturan Mentri Perdagangan Republik Indonesia Nomor: 70/M-DAG/PER/12/2013 pasar tradisional merupakan pasar yang dibangun serta dikelola oleh Pemerintah Daerah, Swasta, Badan Usaha Milik Negara dan Badan Usaha Milik Daerah termasuk kerjasama dengan swasta berupa tempat usaha yang berbentuk toko, kios, los, dan tenda yang dimiliki/dikelola oleh pedagang kecil, menengah, koperasi dengan usaha skala kecil, modal kecil dan melalui proses jual beli barang dagangan dengan tawar-menawar.

Peraturan Menteri Dalam Negeri Republik Indonesia Nomor 20 tahun 2012 tentang Pengelolaan dan Pemberdayaan Pasar Tradisional menjelaskan bahwa penataan pasar tradisional sangat diperlukan agar tercipta pasar yang tertib, teratur, aman bersih dan sehat sehingga mampu bersaing dengan pasar modern.

Kecamatan Lubuk Alung merupakan salah satu penunjang ekonomi di Kabupaten Padang Pariaman. Sejak tahun 1936 pasar Nagari Lubuk Alung merupakan pasar tradisional yang cukup berkembang di Kecamatan Lubuk
Alung. Berdasarkan data profil pasar Kabupaten Padang Pariaman tahun 2016, pasar nagari Lubuk Alung memiliki luas tanah $5.650 \mathrm{~m}^{2}$ dengan luas bangunan $4.950 \mathrm{~m}^{2}$ yang dikelola secara mandiri oleh Penghulu Pasar dan diawasi oleh Komisi Pasar serta dipertanggung jawabkan kepada Kerapatan Adat Nagari Lubuk Alung. Hal ini menyebabkan Pasar Nagari Lubuk Alung merupakan pasar nagari yang mencakup kebutuhan masyarakat di Kecamatan Lubuk Alung.

Pada tahun 2010 pasar Lubuk Alung pernah terbakar, sebanyak 280 petak kios yang hangus terbakar, kerugian yang dialami para pedagang ditaksir sekitar Rp 600 juta (okezone, 2010). Hal ini membuat pedagang terpaksa berdagang dengan apa adanya. Pasca kebakaran tersebut dibangunlah pasar baru untuk menunjang aktifitas perekonomian masyarakat. Namun setelah dibangun pedagang justru tidak pindah ke pasar baru tersebut. Hal ini menyebabkan pasar baru menjadi terbengkalai, bangunannya pun tidak terawat dengan baik.

Peran pemerintah dan stakeholder sebagai pengelola dan pemegang kebijakan terkait baik produsen, pemasok, pedagang, pembeli dan lembaga yang terkait harus segara menemukan solusi yang tepat agar permasalahan tersebut bisa diselesaikan tanpa merugikan piha Berdasarkan program tersebut pedangang, maupun pembeli hendaknya dapat memanfaatkan pasar baru tersebut agar pasar dapat digunakan sebagaimana 
mestinya, yaitu sebagai penunjang perekonomian masyarakat.

Berdasarkan uraian mengenai latar belakang di atas, penulis tertarik untuk melakukan penelitian terkait hal tersebut dengan judul "Faktor-Faktor Penyebab Pedagang Bertahan di Pasar Lama Kecamatan Lubuk Alung Kabupaten Padang Pariaman".

Dalam Peraturan Presiden

Tentang Penataan dan Pembinaan Pasar Tradisional, Pusat Perbelanjaan dan Toko Modern No. 112 Tahun 2007, pasar adalah area tempat jual beli barang dengan jumlah penjual lebih dari satu baik yang disebut sebagai pusat perbelanjaan, pasar tradisional, pertokoan, mall, plasa, pusat perdagangan maupun sebutan lainnya. Menurut Basu S. (1995) bahwa pasar adalah orang-orang yang mempunyai keinginan untuk puas, uang untuk belanja, dan kemauan untuk membelanjakannya. Pengkategorian pasar tradisional dan pasar modern muncul karena mulai merambahnya pasar swalayan, supermarket, hypermarket dan sebagainya.

Bedasarkan beberapa definisi diatas dapat ditarik kesimpulan bahwa pasar tempat bertemunya penjual dan pembeli yang melakukan transaksi sesuai permintaan dan penawaran. Transaksi terjadi ketika sudah ada kesepakatan tentang harga barang dan jasa tanpa ada unsur paksaan.

\section{A. Faktor yang Mempengaruhi Pasar \\ Pembangunan pasar yang menjadi pusat ekonomi tidak terlepas dari pembangunan wilayah. Nugroho (2004)}

menjelaskan bahwa dalam pengambilan keputusan dikaitkan dengan lokasi maupun jarak sehingga orientasi keuntungannya tinggi. Nugroho juga menjelaskan bahwa "Dalam pengambilan keputusan yang berkaitan dengan lokasi dikelompokan menjadi dua yaitu, yang berkaitan langsung (locational factors) dan tidak langsung (non-locational factors)".

\section{Berkaitan Langsung dengan} Faktor Lokasi (Location Factors)

a. Lokasi

Teori lokasi adalah ilmu yang menyelidiki tata ruang (spatial order) kegiatan ekonomi, atau ilmu yang menyelidiki alokasi geografis dari sumber-sumber yang potensial, serta hubungannya dengan atau pengaruhnya terhadap keberadaan berbagai usaha/kegiatan lebih, baik ekonomi maupaun sosial (Tarigan, 2015). Sedangakan menurut Djojodipuro dalam Suryani (2015) tentang teori lokasi pasar dimana dalam pemilihan lokasi pembangunan pasar tradisional sebaiknya didirikan pada lokasi yang ramai dan luas. Pendirian pasar pada lokasi yang tidak ada aktivitas perdagangannya, sangat sulit diharapkan akan dikunjungi oleh masyarakat.

b. Transportasi

Bowersox (1981), transportasi adalah perpindahan barang atau penumpang dari suatu tempat ke tempat lain, dimana produk dipindahkan ketempat tujuan yang dibutuhkan. Menurut Morlok 
(1978), transportasi didefinisikan sebagai kegiatan memindahkan atau mengangkut sesuatu dari suatu tempat ketempat lain.

c. Harga Sewa Kios atau Ruko

Lahan yang digunakan untuk pembangunan kios atau ruko tentu memiliki nilai ekonomi berupa harga sewa. Menurut Barlowe dalam Pembudi (2008) nilai ekonomi lahan dapat dibedakan menjadi dua yaitu 1) Sewa lahan (contract rent) sebagai pembayaran dari penyewa kepada pemilik dimana pemilik melakukan kontrak sewa dalam jangka waktu tertentu. 2) Keuntungan usaha (economic rent atau land rent) yang merupakan surplus pendapatan diatas biaya produksi atau harga input lahan yang memungkinkan faktor produksi lahan dapat dimanfaatkan dalam proses produksi.

d. Pendapatan Pedagang

Menurut Bangun dalam Surtani (1994) jumlah pendapatan adalah penghasilan dari semua anggota keluarga yang disumbangkan kepada pemenuhan kebutuhan perorangan ataupun keluarga. Pendapatan atau keuntungan ekonomi adalah pendapatan yang diperoleh pengusaha, setelah dikurangi oleh ongkos yang tersembunyi (Sadono Sukirno, 1982).

2. Tidak Berkaitan Langsung dengan Faktor Lokasi (Non Location Factors)

a. Kebijakan Pemerintah.
Menurut Iskandar dalam Ramdhani (2017) kebijakan didefenisikan sebagai serangkaian rencana program, aktivitas, aksi, keputusan, sikap, untuk bertindak maupun tidak bertindak yang dilakukan oleh para pihak (aktoraktor), sebagai tahapan untuk menyelesaikan masalah yang dihadapi. Penetapan kebijakan merupakan suatu faktor penting bagi organisasi untuk mencapai tujuannya.

b. Keadaan lingkungan dan sosial. Menurut Nugroho (2004) Faktorfaktor yang berkaitan dengan kualitas hidup tidak hanya dapat berkaitan dengan peluang pasar, tetapi juga penting bagi peningkatan produktivitas, seperti organisasi bisnis, museum, jalan, kondisi kemsyarakatan, harga rumah dan banguan, serta universitas. Dalam kamus besar bahasa Indonesia, kata sosial berarti segala sesuatu yang berkaitan dengan masyarakat. Pedagang yang telah terbiasa dengan lingkungan lama tentu khawatir dengan lingkungan baru.

\section{B. Sikap}

Menurut W.J Thomas dalam Ahmadi (2009) sikap sebagai suatu kesadaran individu yang menentukan perbuatan-perbuatan yang nyata ataupun yang mungkin akan terjadi di dalam kegiatan sosial. Menurut L.L Thursione dalam Ahmadi (2009) sikap sebagai tingkatan kecenderungan yang bersifat positif atau negatif yang berhubungan dengan aspek psikologi. 
Objek psikologi disini meliputi : simbol, kata-kata, slogan, orang, lembaga, ide dan sebaginya. Orang dikatakan memiliki sikap positif terhadap suatu objek psikologi apabila ia suka (like) atau memiliki sikap yang favorable, sebaliknya orang dikatakan memilki sikap yang negatif terhadap objek psikologi bila ia tidak suka (dislike) atau sikapnya unfavorable terhadap objek psikologi.

\section{METODOLOGI PENELITIAN}

Penelitian ini dilaksanakan di lokasi Pasar Lubuk Alung, Kecamatan Lubuk Alung, Kabupaten Padang Pariaman. Penelitian ini termasuk penelitian yang bersifat kualitatif karena peneliti ingin menganalisis, memotret, dan menggambarkan kondisi pasar di Kecamatan Lubuk Alung. Adapun teknik dalam menentukan informan pada penelitian ini adalah teknik Purposive Sampling. Informan yang dimaksud dalam penelitian ini adalah pedagang dan pembeli.

Karakteristik informan yang dimaksud 1) Pedagang yang sudah lama berdagang minimal 10 tahun. 2) Orang yang setiap hari berdagang di pasar Lubuk Alung. 3) Pedagang yang mempunyai cukup banyak waktu, informasi dan kesempatan untuk dimintai keterangan.

Karakteristik pembeli yang dimaksud adalah 1) Pembeli yang setiap hari atau setiap minggu berbelanja di pasar Lubuk Alung. 2) Pembeli yang mempunyai banyak waktu, dan kesempatan untuk dimintai keterangan.

Sumber data yang digunakan yaitu data primer dan data sekunder. Dimana data primer diperoleh melalui wawancara dengan pedagang dan pembeli yang sedang dijadikan sampel dalam penelitian. Sedangkan data sekunder diperoleh melalui dokumentasi. Teknik pengumpulan data yang dilakukan yaitu observasi partisipasif dan wawancara. Instrumen yang digunakan dalam penelitian ini yaitu pedoman wawancara dan kamera Untuk mendokumentasikan hal-hal yang terkait dengan mengumpulkan data dilapangan. Teknik analisis data yang dilakukan adalah reduksi data, penyajian data dan penarikan kesimpulan.

\section{HASIL DAN PEMBAHASAN Deskripsi Wilayah Penelitian}

Secara astronomis Kecamatan Lubuk Alung terletak pada $100^{\circ} 21^{\prime} 00^{\prime \prime}$ BT dan $0^{\circ} 47^{\prime} 00$ " LS dengan luas daerah $111,63 \mathrm{Km}^{2}$ serta ketinggian dari permukaan laut 25-1000 m dpl (sumber : Statistik Kecamatan Lubuk Alung dalam Angka 2016). Sebelah Utara berbatas dengan Kecamatan 2x11 Kayu Tanam dan Kecamatan Enam Lingkung. Sebelah Selatan berbatas dengan Kecamatan Batang Anai. Sebelah Barat berbatas dengan Kecamatan Sintuk Toboh Gadang dan Kecamatan Ulakan Tapakis. Sebelah Timur berbatas dengan Kabupaten Solok. Kecamatan Lubuk Alung terdiri dari lima nagari dapat dilihat pada tabel 1 sebagai berikut. 
Tabel 1. Luas Daerah Menurut Nagari Kecamatan Lubuk Alung Tahun 2015

\begin{tabular}{|c|c|c|}
\hline No & Nagari & $\begin{array}{c}\text { Luas Daerah } \\
\left(\mathrm{Km}^{2}\right)\end{array}$ \\
\hline 1 & Lubuk Alung & 60,35 \\
\hline 2 & Aie Tajun & 8,64 \\
\hline 3 & Sikabu & 7,57 \\
\hline 4 & Pasie Laweh & 30,32 \\
\hline 5 & Punggung Kasiak & 4,75 \\
\hline \multicolumn{2}{|r|}{ Jumlah } & $111,63 \mathrm{Km}^{2}$ \\
\hline
\end{tabular}

Sumber : Statistik Kecamatan Lubuk Alung Dalam Angka 2016

Berdasarkan jumlah penduduk menurut nagari dapat dilihat pada tabel 2. Berikut gambaran jumlah penduduk menurut nagari dan jenis kelamin di Kecamatan Lubuk Alung.

Tabel 2. Jumlah Penduduk menurut Nagari dan Jenis Kelamin di Kecamatan Lubuk Alung Tahun 2015

\begin{tabular}{|c|c|c|c|c|}
\hline No & Nagari & $\begin{array}{l}\text { Laki- } \\
\text { Laki }\end{array}$ & $\begin{array}{l}\text { Perem } \\
\text { puan }\end{array}$ & Jumlah \\
\hline 1 & $\begin{array}{l}\text { Lubuk } \\
\text { Alung }\end{array}$ & 12.951 & 12.797 & 25.748 \\
\hline 2 & $\begin{array}{l}\text { Aie } \\
\text { Tajun }\end{array}$ & 2.303 & 2.281 & 4.592 \\
\hline 3 & Sikabu & 1.451 & 1.466 & 2.917 \\
\hline 4 & $\begin{array}{l}\text { Pasie } \\
\text { Laweh }\end{array}$ & 2.995 & 2.894 & 5.889 \\
\hline 5 & $\begin{array}{l}\text { Pungg } \\
\text { ung } \\
\text { Kasiak }\end{array}$ & 2.809 & 2.796 & 5.605 \\
\hline \multicolumn{2}{|c|}{ Jumlah } & 22.509 & 22.242 & 44.751 \\
\hline
\end{tabular}

Sumber : Statistik Kecamatan Lubuk Alung Dalam Angka 2016

\section{Profil Pasar Lubuk Alung}

Berdasarkan data profil pasar Kabupaten Padang Pariaman tahun 2016, pasar Lubuk Alung dibangun pada tahun 1936 yang dikelola secara mandiri oleh penghulu pasar atau niniak mamak yang diawasi oleh komisi pasar serta dipertanggung jawabkan kepada Kerapatan Adat Nagari Lubuk Alung. Berdasarkan sejarahnya pasar Lubuk Alung merupakan pasar niniak mamak yang diserahkan oleh orang-orang terdahulu ke saudara/kemenakan melalui surat perjanjian. Pasar ini beroperasi setiap hari serta menjual dan memenuhi kebutuhan masyarakat sehari-hari. Bentuk bangunan di pasar Lubuk Alung rata-rata bangunan semi permanen. Pasar Lubuk Alung memiliki luas tanah $5.650 \mathrm{~m}^{2}$ dan luas bangunan $4.950 \mathrm{~m}^{2}$, terletak pada koordinat $100^{\circ} 17^{\prime} 23,7^{\prime \prime}$ BT - 0040’42,6” LS. Jumlah pedagang di Kecamatan Lubuk Alung berjumlah 261 orang. Yang dikategorikan pedagang los 75 orang, pedagang kios 121 orang dan pedagang dasaran sebanyak 65 orang. (sumber: data profil pasar Kabupaten Padang Pariman 2016). Yang dikelompokkan dari beberapa jenis dagangan yaitu pedagang ikan, daging, telur, sembako, pakaian, cabe dan lain-lain. Selain itu pasar nagari Lubuk Alung merupakan pasar yang memenuhi kebutuhan masyarakat di Kecamatan Lubuk Alung.

Pasar nagari Lubuk Alung sudah beberapa kali mengalami kebakaran. Terhitung pada tahun 1997, 2003, dan 2010 hal ini mengakibatkan banyak kerugian yang dialami pedagang. Pasca kebakaran pedagang masih bertahan 
dengan membangun kios-kios atas inisiatif mereka sendiri.

Berikut ini peta lokasi pasar lama Kecamatan Lubuk Alung Kabupaten Padang Pariaman.

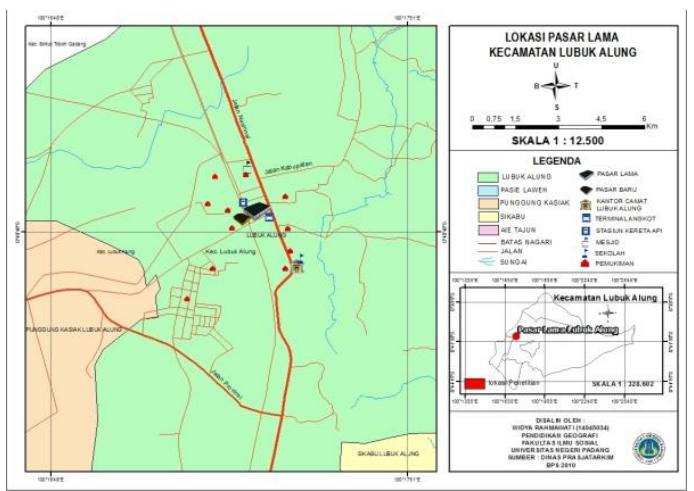

Gambar 1: Peta Lokasi Penelitian

\section{Pembahasan}

Berdasarkan tujuan pada penelitian ini yaitu untuk membahas, menganalisis dan mendeskripsikan tentang faktorfaktor penyebab pedagang bertahan di pasar lama Kecamatan Lubuk Alung Kabupaten Padang Pariaman. Nugroho (2004) menjelaskan bahwa "Dalam pengambilan keputusan yang berkaitan dengan lokasi dikelompokan menjadi dua yaitu, yang berkaitan langsung (locational factors) dan tidak langsung (non-locational factors)'”. Berdasarkan hasil penelitian berupa informasi, faktafakta dilapangan, dilihat dari faktor langsung.

Pertama faktor lokasi, merupakan tata ruang (spatial order) kegiatan ekonomi, atau ilmu yang menyelidiki alokasi geografis dari sumber-sumber yang potensial, serta hubungannya dengan atau pengaruhnya terhadap keberadaan berbagai usaha/kegiatan lebih, baik ekonomi maupaun sosial
(Tarigan, 2015). Jarak antara pasar lama dengan pasar baru cukup dakat, namun dari lokasinya pasar lama lebih strategis karena dekat dengan pemukiman dan jalan raya yang memudahkan pedagang dan pembeli untuk ke pasar lama. Selain itu juga dekat dengan stasiun kereta api dan terminal angkot, sehangga hal ini menguntungkan dan memudahkan untuk bongkar muat barang, serta menarik minat pembeli. Hal ini sesuai dengan teori Djojodipuro dalam Suryani (2015), pemilihan lokasi pembangunan pasar tradisional sebaiknya didirikan pada lokasi yang ramai dan luas. Pendirian pasar pada lokasi yang tidak ada aktivitas perdagangannya, sangat sulit diharapkan akan dikunjungi oleh masyarakat.

Selain itu juga memperhatikan pada lokasi yang strategis. Dengan letak yang strategis, akan memudahkan transaksi jual-beli dari pada pasar yang letaknya kurang strategis. Dalam hal ini ada berbagai faktor yang mempengaruhi seperti keramaian lalu lintas, kemungkinan tempat pemberhentian orang berbelanja, keadaan penduduk dilingkungan pasar, keadaan parkiran dan sebagainya. Jika dilihat dari lokasinya jarak antara rumah pedagang dengan pasar lama Kecamatan Lubuk Alung cukup dekat dan mudah di jangkau, jarak rata-rata $\leq 3 \mathrm{Km}$.

Kedua transportasi, menurut Morlok (1978), transportasi didefinisikan sebagai kegiatan memindahkan atau mengangkut sesuatu dari suatu tempat ketempat lain. Pada umumnya transportasi yang digunakan adalah kendaraan sepeda motor, namun ada juga yang menggunakan angkutan 
umum atau jalan kaki. Kondisi jalan menuju pasar Lubuk Alung sudah baik, dan letak pasar yang dekat jalan raya memudahkan pedagang dan pembeli untuk ke pasar, sehingga aksesibilitasnya tinggi. Selain itu transportasi yang dapat digunakan untuk ke pasar Lubuk Alung seperti menggunakan transportasi umum dan pribadi. Kendaraan yang memalui kedua pasar ini, khusus untuk sarana prasarana transportasi, peneliti tidak menemukan hal yang terlalu berarti.

Ketiga sewa kios, Lahan yang digunakan untuk pembangunan kios atau ruko tentu memiliki nilai ekonomi berupa harga sewa. Menurut Barlowe dalam Pembudi (2008) sewa lahan (contract rent) sebagai pembayaran dari penyewa kepada pemilik dimana pemilik melakukan kontrak sewa dalam jangka waktu tertentu. Sebagai pelaku ekonomi pedagang tentu akan lebih tertarik pada harga sewa yang terjangkau karena akan menguragi pengeluaran.

Seperti yang dinyatakan oleh Ibu Darlina, beliau menuturkan jika pindah tentu akan menambah uang sewa, kalau di pasar lama hanya membayar sewa tanah saja, sedangkan kalau pindah ke pasar baru pasti akan ditambah dengan sewa bangunan. Berdasarkan data tersebut alasan pedagang bertahan di pasar lama Kecamatan Lubuk Alung karena harga sewa kios yang terjangkau oleh pedagang, sebagian pedagang memiliki tempat usaha sendiri dan sebagian ada membayar sewa tanah setiap tahunnya sekitar Rp 500.000 Rp 1.500 .000 pertahun. Dengan demikian hal ini bisa memperkecil pengeluran pedagang, sedangkan di pasar baru biaya sewa yang dikeluarkan sekitar Rp 3.000.000 - Rp 5.000.000 pertahun. Harga ini lebih mahal dibandingkan dari biaya sewa di pasar lama Kecamatan Lubuk Alung.

Keempat pendapatan, jika dilihat pada pasar baru aktivitas perdagangannya masih kurang, sangat sulit diharapkan akan dikunjungi oleh masyarakat atau pembeli. Seperti yang dinyatakan oleh Ibu Disneli, beliau mengatakan bahwa dilihat dari kenyamanannya pasar baru cukup nyaman, tapi kurangnya pembeli disana. Dulu disuruh pindah, karena tidak ada jual beli kembali lagi ke pasar lama. Walaupun tempatnya bagus dan bersih tapi tidak ada pemasukan disana, orang pasti tidak mau berdagang disana.

Rata-rata pendapatan pedagang di pasar lama berkisar Rp 500.000 - Rp 1.000.000 perhari dengan keuntungan yang di dapat yaitu Rp 250.000 - Rp 500.000 perhari. Hal ini dapat disimpulkan pendapatan juga mempengaruhi faktor penyebab pedagang bertahan di pasar lama Kecamatan Lubuk.

Selanjutnya faktor tidak langsung yang mempengaruhi faktor-faktor penyebab pedagang bertahan di pasar lama Kecamatan Lubuk Alung Kabupaten Padang Pariaman, yaitu pertama dilihat dari kebijakan pemerintah. Menurut Iskandar dalam Ramdhani (2017) kebijakan didefenisikan sebagai serangkaian rencana program, aktivitas, aksi, keputusan, sikap, untuk bertindak maupun tidak bertindak yang dilakukan oleh para pihak (aktor-aktor), sebagai 
tahapan untuk menyelesaikan masalah yang dihadapi. Penetapan kebijakan merupakan suatu faktor penting bagi organisasi untuk mencapai tujuannya.

Kebijakan pemerintah diatur dalam UU nomor 22 tahun 1999 dimana pemerintah memberi kewenangan kepada daerah untuk mengatur wilayahnya masing-masing. Kebijakan pemerintah ataupun stakeholder membangun lokasi pasar baru Lubuk Alung agar ekonomi masyarakat meningkat dan menciptakan pasar baru yang lebih bersih. Namun faktanya pasar yang telah dibangun belum beroperasi secara dengan baik. Hal ini tak lepas dari peran pedagang dan pembeli untuk mensukseskan pasar.

Faktor pedagang bertahan karena, pasca kebakaran tidak ada ketegasan secara resmi oleh pengelola pasar untuk memindahkan pedagang dari pasar lama ke pasar baru. Pedagang sudah nyaman dan betah di pasar lama karena rata-rata mereka berdagang sudah puluhan tahun, walaupun dengan kondisi pasar lama seperti sekarang. Jika pedagang pindah ke pasar baru, pedagang harus mencari pelanggan baru, dan harus beradaptasi dengan lingkungan yang baru. Di pasar baru Lubuk Alung belum ada kejelasannya, karena untuk membayar uang sewa tanah ke pihak BUMN, sedangkan untuk sewa bangunan ke pihak swasta, hal ini membuat pedagang menjadi tidak nyaman.

Hubungan sosial kemasyarakatan pedagang dengan lingkungan sekitar sudah terjalin dengan baik, hal ini dilihat dari adanya ikatan antar pedagang yaitu IKAPILA (Ikatan Pedagang Pasar Lubuk Alung). Dalam paguyuban ini pedagang saling bergotong royong untuk memperbaiki dan menjaga pasar. Seperti ronda yang dilakukan oleh pedagang setiap malam atas inisiatif para pedagang sendiri untuk menciptakan pasar yang aman.

Pasca kebakaran K3 di pasar lama Lubuk Alung sangat kurang, tidak ada bak sampah sehingga banyak sampah yang menumpuk, dan kondisi jalan yang sempit menyulitkan pedagang maupun pembeli dalam jual beli. Apabila hujan, pasar lama Lubuk Alung menjadi becek dan banjir karena saluran air atau drainase yang tersumbat sampah.

Dilihat dari ketertibannya pasar lama Lubuk Alung belum tertata rapi, tidak ada pengelompokkan pedagang sesuai jenis dagangannya. Jika dilihat di pasar baru kebersihannya cukup bersih, ketika hujan pun tidak becek karena saluran air atau drainase langsung menuju selokan. Jalannya pun sudah di aspal, namun sangat disanyangkan ruko-ruko yang tidak terpakai menjadi terbengkalai dan tidak terawat, sehingga menjadi rusak.

Menurut L.L Thursione dalam Ahmadi (2009) sikap sebagai tingkatan kecenderungan yang bersifat positif atau negatif yang berhubungan dengan aspek psikologi. Dengan adanya pembangunan pasar baru timbulnya pro dan kontra di masyarakat. Jika dilihat dari sikap pedagang beberapa setuju, karena dipasar baru lebih bersih, tidak becek saat hujan karena saluran air langsung menuju selokan. Namun mereka tetap bertahan karena belum ada pedagang yang pindah ke pasar baru dan kondisi pasar baru yang masih sepi. Beberapa pedagang mengatakan tidak 
setuju, karena status pasar baru yang belum jelas, pedagang sudah nyaman di pasar lama karena rata-rata mereka berdagang sudah puluhan tahun, biaya sewa yang mahal, kurangnya minat pembeli, dan kalah saing dengan grosir.

Jika dilihat dari sikap pembeli, beberapa berpendapat tidak setuju karena, jarak dari terminal ke pasar baru cukup jauh, sehingga menyulitkan pembeli untuk berjalan kaki, barang yang ada di pasar baru belum lengkap, seperti bahan dapur dan barang kebutuhan sehari-hari lainya. Kalau dipasar lama barang yang di jual lengkap dengan harga yang terjangkau, juga banyak pilihan. Bebarapa pembeli ada yang setuju karena, di pasar baru lebih bersih dan teratur, jalannya lebih besar dan sudah diaspal, tapi yang kurang dipasar baru jenis dagangannya tidak lengkap, sehingga pembeli memilih berbelanja di pasar lama Lubuk Alung.

\section{KESIMPULAN}

Berdasarkan hasil temuan dilapangan melalui observasi dan wawancara peneliti dapat mengambil kesimpulan Faktor-Faktor Penyebab Pedagang Bertahan di Pasar Lama Kecamatan Lubuk Alung Kabupaten Padang Pariaman sebagai berikut.

Berdasarkan hasil temuan dilapangan melalui observasi dan wawancara peneliti dapat mengambil kesimpulan faktor-faktor penyebab pedagang bertahan di pasar lama Kecamatan Lubuk Alung Kabupaten Padang Pariaman sebagai berikut.
1. Faktor yang berkaitan langsung (locational factors) dan tidak langsung (non-locational factors).

a. Faktor Langsung

1) Lokasi, jarak antara rumah pedagang dengan pasar lama Kecamatan Lubuk Alung cukup dekat dan mudah di jangkau, jarak rata-rata $\leq 3 \mathrm{Km}$.

2) Transportasi yang digunakan adalah kendaraan sepeda motor, namun ada juga yang menggunakan angkutan umum atau jalan kaki.

3) Sewa kios yang dikeluarkan pedagang di pasar lama Kecamatan Lubuk Alung sudah terjangkau, sebagian pedagang memiliki tempat usaha sendiri dan sebagian membayar sewa tanah setiap tahunnya sekitar Rp 500.000 - Rp 1.000.000 pertahun. Dengan demikian hal ini bisa memperkecil pengeluran pedagang, sedangkan di pasar baru biaya sewa yang dikeluarkan sekitar Rp 3.000.000 - Rp 5.000.000 pertahun.

4) Rata-rata pendapatan pedagang berkisar Rp $500.000 \quad-\mathrm{Rp}$ 1.000.000 perhari dengan keuntungan yang di dapat yaitu Rp 250.000 - Rp 500.000 perhari.

b. Faktor Tidak Langsung

1) Kebijakan pemerintah, pasca kebakaran tidak ada ketegasan secara resmi oleh pengelola pasar untuk memindahkan pedagang dari pasar lama ke pasar baru. Pedagang sudah nyaman dan betah di pasar lama karena ratarata mereka berdagang sudah 
puluhan tahun, walaupun dengan kondisi pasar lama seperti sekarang, dan belum ada status yang jelas dari pasar baru.

2) Keadaan lingkungan dan sosial, hubungan sosial kemasyarakatan pedagang dengan lingkungan sekitar sudah terjalin dengan baik, hal ini dilihat dari adanya ikatan antar pedagang yaitu IKAPILA (Ikatan Pedagang Pasar Lubuk Alung). Dalam paguyuban ini pedagang saling bergotong royong untuk memperbaiki dan menjaga pasar. Pasca kebakaran kebersihan dan ketertiban di pasar lama Lubuk Alung sudah berkurang.

2. Sikap pedagang dan pembeli ada yang setujua dan ada yang tidak setuju dengan adanya pasar baru. Beberapa pedagang mengatakan tidak setuju, karena status pasar baru yang belum jelas, pedagang sudah nyaman di pasar lama karena rata-rata mereka berdagang sudah puluhan tahun, biaya sewa yang mahal, kurangnya minat pembeli, dan kalah saing dengan grosir. beberapa berpendapat tidak setuju karena, jarak dari terminal ke pasar baru cukup jauh, sehingga menyulitkan pembeli untuk berjalan kaki, barang yang ada di pasar baru belum lengkap, seperti bahan dapur dan barang kebutuhan sehari-hari lainya. Bebarapa pembeli ada yang setuju karena, di pasar baru lebih teratur, jalannya lebih besar dan sudah diaspal, tapi yang kurang dipasar baru jenis dagangannya tidak lengkap, sehingga pembeli memilih berbelanja di pasar lama Lubuk Alung.

\section{SARAN}

Berdasarkan hasil penelitian dan kesimpulan yang dikemukaan di atas maka peneliti memberikan saran sebagai berikut.

a. Untuk pengelola pasar memberikan sosialisasi, dan memindahkan pedagang secara bertahap, selain itu menurunkan harga sewa kios/ruko di pasar baru serta menyediakan fasilitas yang memadai.

b. Untuk Wali Nagari Lubuk Alung di harapkan untuk melakukan revitalisasi pasar dengan melibatkan para pedagang dan forum komunikasi dahulu, untuk menjaring aspirasi pedagang agar terwujudnya kenyamanan dan kemajuan pasar.

\section{DAFTAR PUSTAKA}

Ahmadi, Abu. (2009). Psikologi Sosial. Jakarta: Rineka Cipta.

Badan Pusat Statistik (BPS). (2016). Kacamatan Lubuk Alung Dalam Angka. Padang Pariaman: BPS Kabupten Padang Pariaman.

Bowersox, C. (1981). Introduction to Transportation. New York: Macmillan Publishing Co, Inc.

Morlok, Edward K. (1978). Pengantar Teknik dan Perencanaan Transportasi. Jakarta: Erlangga.

Nugroho, Iwan. (2004). Pembangunan Wilayah : Perspekstif ekonomi, sosial, dan lingkungan. Jakarta : LP3ES.

Pembudi, Andika. (2008). Analisis Nilai Ekonomi Lahan (Land Rent) pada Lahan Pertanian dan Pemukiman 
di Kecamatan Ciampea, Kabupaten Bogor. Jurnal. Fakultas Pertanian Institut Pertanian Bogor. (Skripsi).

Ramdhani, Abdullah. (2017). Konsep Umum dalam Pelaksanaan Kebijakan Publik. Vol 11;No. 01; 2017;1-12.

Sugiyono. (2006). Metode Penelitian Kuantitatif, Kualitatif dan R\&D. Bandung : Alfabeta.

Suharno. (2010). Dasar-Dasar Kebijakan Publik. Yogyakarta: UNY Press.

Sukirno, Sadono. (1982). Pengantar Teori Mikro Ekonomi. Bima : BG. Grafika.

Surtani. (1994). Studi Tentang Tingkat Pendapatan dan Pemasaran Sebelum dan Sesudah Adanya Tempat Pelelangan Ikan (TPI) di Kecamatan Bungus Teluk Kubung Kodya Padang. Jurnal. IKIP Padang.

Suryani, Yosi. (2015). Teori Lokasi Dalam Penentuan Pembangunan Lokasi Pasar Tradisional (Telaah Studi Literatur). Jurnal. UNP.

Swastha, Basu. (1995). Pengantar Bisnis Modern. Jakarta : Liberty.
Tarigan, Robinson. (2015). Perencanaan Pembangunan Wilayah (Edisi Revisi). Jakarta: PT. Bumi Aksara. (2016). Profil Pasar Kabupten Padang Pariaman. BPS Kabupaten Padang Pariaman.

(2013). Peraturan Menteri Perdagangan Republik Indonesia Nomor: 70/M-DAG/PER/12/2013 tentang Pedoman Penataan dan Pembinaan Pasar Tradisional, Pusat Perbelanjaan dan Toko Modern.

(2007). Peraturan Presiden

Tentang Penataan dan Pembinaan Pasar Tradisonal, Pusat Perbelanjaan dan Toko Modern Nomor 112. .(2012). Peraturan Menteri Dalam Negeri Republik Indonesia Nomor 20 tentang Pengelolaan dan Pemberdayaan Pasar Tradisional. .(1999). Undang - undang Nomor 22 tentang Pemerintahan Daerah.

https://news.okezone.com/read/2010/02/ 07/340/301170/api-amuk-280petak-toko-pasar-lubuk-alung. 